\title{
Start Up of a UASB Treating Malted Ingredient Manufacturing Wastewater
}

\author{
Ryland Cairns (Corresponding author) \\ Fontus Environmental, Thirsk, North Yorkshire, England \\ Email: Ryland@fontusenvironmental.com \\ Paul Mead \\ Muntons, Cedar Maltings, Stowmarket, Suffolk, England \\ E-mail: Paul.Mead@muntons.com
}

Received: January 4, 2018 Accepted: January 22, 2018

doi:10.5296/emsd.v7i2.12411ＵRL: https://doi.org/10.5296/emsd.v7i2.12411

\begin{abstract}
With a greater push to achieve waste management and renewable energy targets technologies such as anaerobic digestion (AD) have increased in popularity. One such technology option is the Upflow Anaerobic Sludge Blanket (UASB) reactor, these have been shown to be a particularly robust option for high strength organic wastewaters, such as those generated by the malted ingredient manufacturing industry. Despite their effectiveness they are reported to have lengthy and complex start ups due to the range of physiochemical and biological interactions influencing sludge blanket stability. This process can be sped up by seeding the plant from sludge from similar plants, however this is not always possible. This paper aims to investigate the start up of a full-scale mesophilic UASB treating malted ingredient wastewater that was initially seeded with a granular sludge treating dairy wastewater. Operational performance during the first 75 days of start up was comparable to that of a fully established plant with a COD removal efficiency in excess of $81.89 \%$ and a biogas methane concentration greater than $57.24 \%$. During this period the plant remained operationally robust with the Organic Loading Rates (OLR) exuding the greatest influence on plant performance. Similar to operations during stable conditions key operational parameters such as HRT times, temperatures and $\mathrm{pH}$ did not exert a strong influence on the plant.
\end{abstract}

Keywords: Anaerobic Digestion, Start up, UASB, Malt, Wastewater, Trade effluent 


\section{Introduction}

Anaerobic digestion (AD) is a technology that has gained popularity in recent years for its effective treatment of organic waste streams (ADBA, 2016). It holds significant benefits over aerobic treatment due to its low construction costs, low operational footprint, low sludge production, and green energy production through the production of biogas (Singh et al., 2013). From an operational perspective it is considered robust in terms of Chemical Oxygen Demand (COD) removal (Conceição et al., 2013), pH stability and recovery time (Hernández and Rodríguez, 2013) as well as relatively simple operation and management of plant (Singh et al., 2013). This has led to organisations constructing AD plants to achieve various waste management targets and renewable energy goals (Bekkering et al., 2016)

A popular form of treatment for medium to high strength effluents is Upflow Anaerobic Sludge Blankets (UASBs) (Musee et al., 2016), which have demonstrated high reliability both in terms of their COD removal efficiencies (typically >80\%) and biogas $\mathrm{CH}_{4}$ concentrations (typically $>50 \%$ ) (Latif et al., 2011). This performance has been documented in a number of studies treating a wide range of wastewaters including: Palm oil mill effluent (Siang, 2006); Paper mill wastewater (Kamali et al., 2016); Distillery wastewater (Musee et $a l ., 2016$ ); dairy wastewater (Tawfik et al., 2008); fishery wastewater (Huang et al., 2009); slaughterhouse wastewater (Chavez et al., 2005); Piggery effluent (Huang et al., 2005) municipal wastewater (Rivzi et al., 2015), malting's steep water (Borzacconi et al., 2006) and malt ingredients factory wastewater (Cairns and Mead, 2017).

Despite the robust operational performance, UASBs are reported as complex to start up with long start up times (Rivzi et al., 2015). The length of this start up procedure is governed by a number of complex and interrelated factors which influence the development of the sludge blanket such as wastewater characterisation, the sludge used to seed the plant, $\mathrm{pH}$, nutrient ratio, inhibitory compounds, hydraulic and organic loading rates, up flow velocity, mixing effectiveness and reactor design (Zhang et al., 2012).

The stabilisation of the sludge blanket within a newly seeded plant can be influenced by a range of operational factors associated with both the new plant and the plant that the sludge originated from including wastewater composition, type of reactor, sludge temperature nutrient content and $\mathrm{pH}$ (Singh et al., 1997). When sludge conditions of a UASB closely match those of where the sludge seed originates from start up can be achieved in less than a week (Wolmarans and Villiers, 2002). Although, when wastewater, reactor design and temperature are different from where the sludge seed originates it has been shown to take up to 17 weeks for the plant to effectively start up (Rizvi et al., 2014).

Due to the cost and lack of availability of granular biomass, self seeding is a potential option. Previous studies indicating start up times of 6 to 17 weeks (Lettinga et al.,1993; Kalago and Verstraete, 2001; Yu et al., 2001; Alvarez, et al., 2006). with effectiveness influenced by a number of physiochemical and biological interactions (Schmidt and Ahring, 1996).

It has been demonstrated that UASBs are a suitable technology option for the treatment of wastewater generated by the malted ingredient (MI) manufacturing industry (Cairns and 


\section{MInstitute ${ }_{\text {Int }}^{\text {Macrothink }}$}

Mead, 2017). However the potential lack of sludge from similar plants is likely to make start up of new reactors challenging. Additionally, the lack of literature relating to the start up of UASBs treating MI wastewater could potentially reduce the uptake of this technology as a treatment option for this type wastewater.

The present study investigates the start up of a mesophilic UASB treating a MI manufacturing wastewater that has been seeded with a mesophilic granular sludge from a UASB treating dairy wastewater. Trends in the treated effluent quality in relation to UASB process parameters over the first 150 days are to be presented as well as the impact of the Organic Loading Rate on COD removal and methane production.

\section{Materials and Methods}

\subsection{Plant Layout}

This paper investigates the start-up of a UASB reactor at a UK based Malted Ingredients Factory. The reactor had featured in a previous study which covered its performance under stable operational conditions (Cairns and Mead, 2017). The processes of producing liquid and dried malt extract ingredients (evaporator, band drier, spray drier, ultra filter and canning) from malted barley grain generates a variety of wastewaters that constitute the feed in to the reactor. The volume, temperature and concentration of the wastewater will naturally vary depending on process equipment being used even though the organic material originates from malt. A full process description is provided alongside a process flow diagram for the AD plant (Figure 1) and plant design parameters (Table 1), as covered in Cairns and Mead (2017).

Table 1. Process Design

\begin{tabular}{|l|l|l|}
\hline Parameter & Units & Design Value \\
\hline Flow (Q) & $\mathrm{m}^{3} / \mathrm{d}$ & $200(280 \mathrm{max})$ \\
\hline Chemical Oxygen Demand (COD) & $\mathrm{mg} / \mathrm{L}$ & 40,000 \\
\hline Hydraulic Retention Time (HRT) & days & $10(7 \mathrm{~min})$ \\
\hline Organic Loading Rate $(\mathrm{OLR})$ & $\mathrm{Kg} \mathrm{COD} / \mathrm{m}^{3} / \mathrm{day}$ & $4(5.6 \mathrm{max})$ \\
\hline Organic Nitrogen $(\mathrm{TKN})$ & $\mathrm{mg} / \mathrm{L}$ & 110 \\
\hline Ammonia $\left(\mathrm{NH}_{3}\right)$ & $\mathrm{mg} / \mathrm{L}$ & 16 \\
\hline Total Phosphorus $(\mathrm{P})$ & $\mathrm{mg} / \mathrm{L}$ & 230 \\
\hline Total Suspended Solids (TSS) & $\mathrm{mg} / \mathrm{L}$ & 2,000 \\
\hline Sulphate $\left(\mathrm{SO}_{4}{ }^{2-}\right)$ & $\mathrm{mg} / \mathrm{L}$ & 380 \\
\hline
\end{tabular}

From the MI factory the raw wastewater passes through a $1 \mathrm{~mm}$ drum screen to remove coarse solids and in to a $650 \mathrm{~m}^{3}$ buffer tank to aid with flow balancing. Wastewater is pumped from the buffer tank and in to a conditioning tank $\left(64 \mathrm{~m}^{3}\right)$ where temperature is regulated via a chiller unit which is automatically controlled to ensure the effluents is with the mesophilic digestion range $\left(35^{\circ} \mathrm{C}-38^{\circ} \mathrm{C}\right)$. The conditioned wastewater is pumped in to the $2047 \mathrm{~m}^{3}$ Enprotech UASB where it percolates up through the sludge blanket comprising granular biomass. The plant was seeded by $10 \mathrm{~T}$ of biomass that originated from a mesophilic UASB reactor treating dairy wastewater. Mixing within the reactor is hydraulic in nature with a homogenous blend being achieved via the sequenced opening/closing of actuator valves to 
regulate flows to different parts of the reactor. A three phase separator is used at the top of the reactor to separate the wastewater, biomass and biogas. Biogas from the reactor is collected within a $400 \mathrm{~m}^{3}$ Biodome prior to it being passed through to a Combined Heat and Power unit with a 499kW MAN engine. Treated effluent goes on for further treatment via conventional activated sludge treatment prior to it being discharged under an Environmental Permit to a local watercourse. The Waste Activated Sludge from this biological aerobic treatment is dewatered and send to local farm land to provide agricultural benefit. Due to the close proximity of the AD plant to the activated sludge plant off-gas from the UASB reactor can be treated aerobically by feeding it through the activated sludge reactor to reduce foul smells, this forms part of the plants odour management plan. The separated biomass is retained within the reactor and settles out in the sludge blanket.

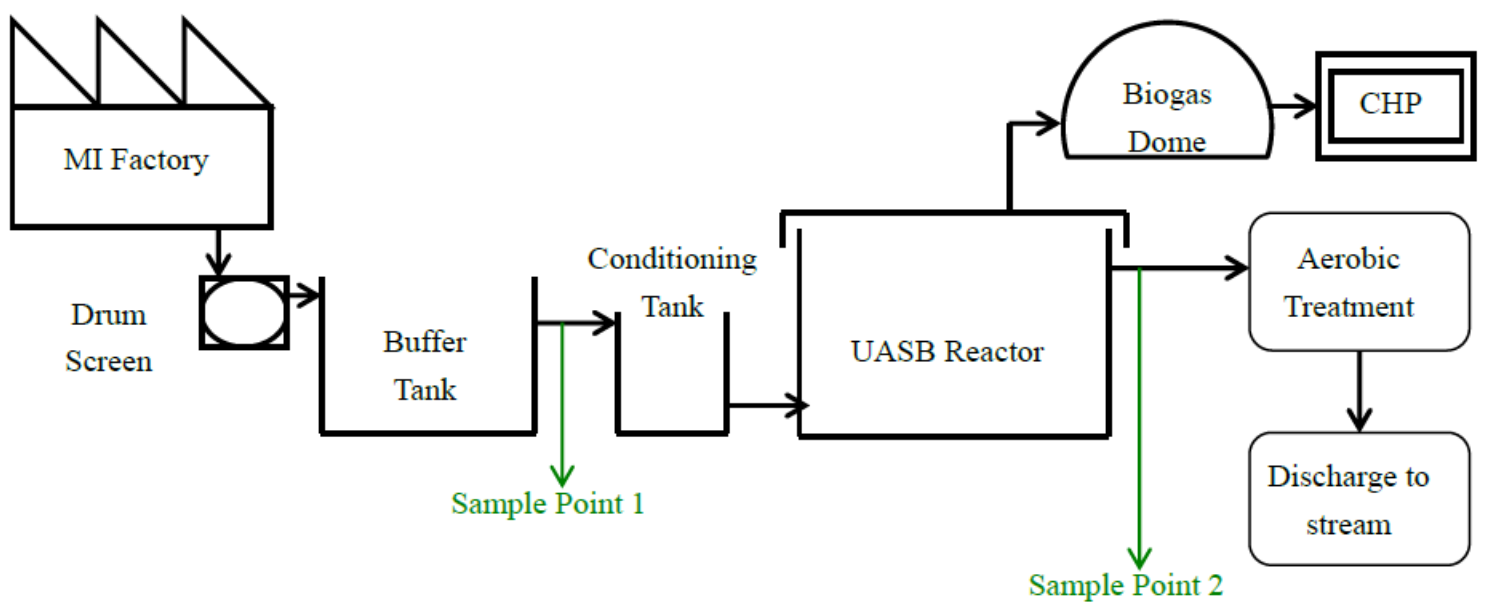

Figure 1. Basic layout of the AD plant (Cairns and Mead, 2017)

\subsection{Characterization of MI Wastewater and Treated Wastewater}

Composition of wastewaters from the MI production process varies considerably (Cairns and Mead, 2017) as a result of incoming wastewater streams from different production processes (such as band drier, spray drier, ultra-filtration, canning operations). çTo ensure testing was representative of the actual feed to the UASB plant samples were collected daily from the outlet of the buffer tank (Figure 1; Sample Point 1). A daily sample of the treated wastewater was taken directly after the UASB reactor (Figure 1; Sample Point 2) to demonstrate plant performance during start up. The analysis in this study represents the initial 150 days of operation between 02/04/2015 and 01/08/2015.

Standard methods for the examination of water and wastewater (APHA et al., 2012) were used to determine the physiochemical properties of both the treated and untreated wastewater. Analysis was performed by trained technicians within the in-house laboratory and included tests for the following: Chemical Oxygen Demand, total Kjeldahl Nitrogen, Ammonia, Total Phosphorus, Total Suspended Solids (TSS), pH and sulphate.

Due to various snagging the plant lacked a gas analyser and gas production meter during start up. A gas usage meter was in place however due to engine availability this did not provide a 
clear indication of plant performance in to the amount or composition of the biogas produced.

\section{Results and Discussion}

\subsection{Characterization of Untreated Wastewater}

Table 2 shows the composition of the raw wastewater over the 150 day start up period which includes the range of daily figures as well as means and standard deviation.

Influent COD concentration ranged from $15,619 \mathrm{mg} / \mathrm{L}$ to $44,684 \mathrm{mg} / \mathrm{L}$ with an associated mean of $26,837 \mathrm{mg} / \mathrm{L}$ (STD $\pm 6,124$ ); organic nitrogen levels ranged from $132 \mathrm{mg} / \mathrm{L}$ to $561 \mathrm{mg} / \mathrm{L}$ (mean $372 \mathrm{mg} / \mathrm{L}$ ) and phosphorus from $3.58 \mathrm{mg} / \mathrm{L}$ to $180 \mathrm{mg} / \mathrm{L}$ (mean of $106.9 \mathrm{mg} / \mathrm{L}$ ) This results in a mean CNP ratio of roughly 250:3:1 during the start up period. This is similar the mean CNP ratio recorded over the subsequent 600 days at a ratio of 234:3:1 (Cairns and Mead, 2017). From a macronutrient perspective it has been highlighted that for optimum $\mathrm{CH}_{4}$ yield a CNP ratio of 100:3:1 is desired. For the current wastewater a CNP of 234:3:1 was apparent, this high $\mathrm{C}$ to NP ratio could lead to a deficiency in the process with a poor buffering capacity (Rajeshwari et al., 2000) and as such pH should be monitored closely.

Both ammonia and sulphate were at levels that would not inhibit the start up procedure with ammonia concentration ranging from of $1.28 \mathrm{mg} / \mathrm{L}$ to $73.80 \mathrm{mg} / \mathrm{L}$ (mean $10.41 \mathrm{mg} / \mathrm{L}$ $\mathrm{STD} \pm 13.06$ ) giving a mean COD:NH3 ratio of 2578:1, whilst Sulphate ranged from 136mg/L to $919 \mathrm{mg} / \mathrm{L}$ with a mean of $465.15 \mathrm{mg} / \mathrm{L}(\mathrm{STD} \pm 143.49)$ giving a mean $\mathrm{COD}: \mathrm{SO}_{4}$ ratio of 58:1. This is in excess of the design limit which has states the maximum concentration value as $380 \mathrm{mg} / \mathrm{L}$. Total Suspended Solids (TSS) were also found to be in excess of their design limit with a mean value of $2,104 \mathrm{mg} / \mathrm{L}(\mathrm{STD} \pm 1,112)$ being compared to the $2000 \mathrm{mg} / \mathrm{L}$ maximum concentration.

Table 2. Untreated MI Wastewater Composition

\begin{tabular}{|l|l|l|}
\hline Parameter & Range & Mean \\
\hline Chemical Oxygen Demand (COD) (mg/L) & $15,619-44,684$ & $26,837 \pm 6,124$ \\
\hline Organic Nitrogen (TKN) (mg/L) & $132.00-561.00$ & $233.51 \pm 83.06$ \\
\hline Ammonia (mg/L) & $1.28-73.80$ & $10.41 \pm 13.06$ \\
\hline Phosphorus (mg/L) & $3.58-180.00$ & $106.09 \pm 39.25$ \\
\hline Total Suspended Solids (TSS) (mg/L) & $682-9,828$ & $2,104 \pm 1,112$ \\
\hline pH & $3.15-11.83$ & $4.50 \pm 1.88$ \\
\hline Sulphate (mg/L) & $136.00-919.00$ & $465.15 \pm 143.49$ \\
\hline
\end{tabular}

Predominantly the $\mathrm{pH}$ of the wastewater was acidic with a mean of 4.05 (STD \pm 1.14 ) and a range of 8.49 (spanning form 3.15 to 11.83). This large range was a result of caustic cleans of the processing equipment with the factory that pushed the $\mathrm{pH}$ in excess of 7.00 for a total of 10 days $(6.66 \%$ of sampling period).

The characterisation of the wastewater presented in Table 2 is similar to the results observed in Cairns and Mead (2017) which carries on to state that although the values of these parameters are typical of results obtained from UASBs treating different effluents types there were no similar characterization profiles even amongst other industries involved in the 
processing of grains (Erashin et al., 2011; Rajeshwari et al., 2000 and Latif et al., 2011). Considering different MI processing equipment is expected to influence both the volume and strength of the wastewater future studies should examine the constituent inputs that make up the final raw wastewater.

\subsection{Start-up: Reactor Conditions}

A number of conditions were measured during the start up the reactor including flow, COD, temperature, $\mathrm{pH}$, volatile fatty acids and the organic loading rates. Daily trends are show in Figures 2- 7 whilst mean figures for 30 day periods are shown in table 4.

Feed to the UASB was gradually increased from $22 \mathrm{~m}^{3} / \mathrm{d}$ to $215 \mathrm{~m}^{3} / \mathrm{d}$ by the $30^{\text {th }}$ day (Figure 2). Between the $30^{\text {th }}$ and $75^{\text {th }}$ day flow fluctuated greatly between $113 \mathrm{~m}^{3} / \mathrm{d}$ to $265 \mathrm{~m}^{3} / \mathrm{d}$ with the greatest difference in flow between being $134 \mathrm{~m}^{3} / \mathrm{d}$. After this the flow in to the plant stabilised at $214 \mathrm{~m}^{3} / \mathrm{d}(\mathrm{STD} \pm 29.5)$. Table 4 shows that after the initial 60 days mean flow was in excess of operational design value of $200 \mathrm{~m}^{3} / \mathrm{d}$ for the remainder of the start up. Despite this being under the maximum design limit it was in excess of the expected operational conditions.

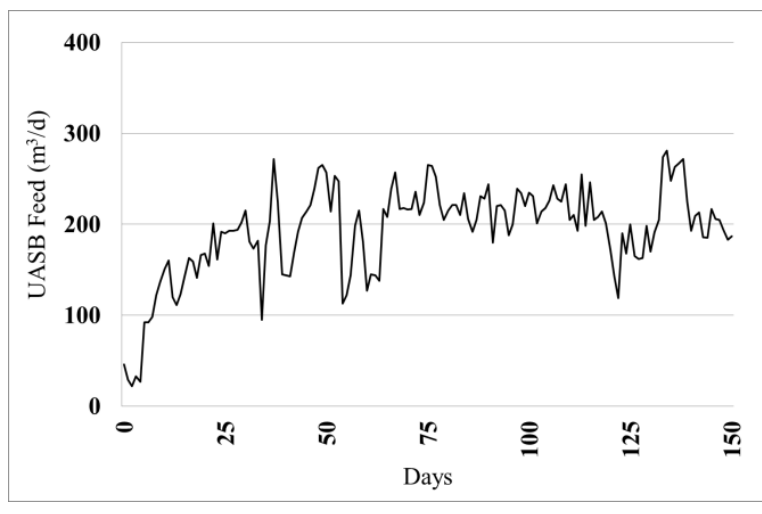

Figure 2. Feed to UASB $\left(\mathrm{m}^{3} / \mathrm{d}\right)$

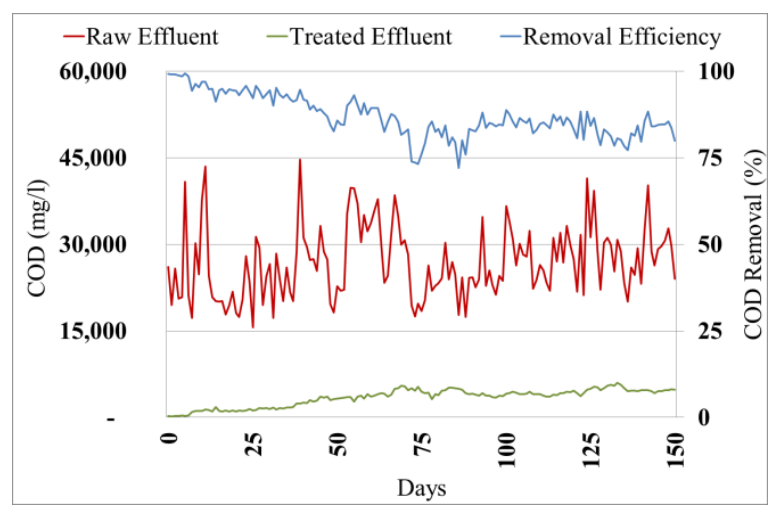

Figure 3. COD concentration and removal

These great differences in flow were due to operators responding to the daily fluctuations in COD concentrations from the incoming wastewater (Figure 3) and attempting to gradually step up the organic loading rate (OLR) until conditions had stabilised (Figure 4). Previous studies (Alphenaar, 1994) had indicated that large fluctuations in OLR prior to system stabilization could have a deleterious impact on plant performance. For this reason after the initial 75 days of start up OLR was maintained at a mean of $2.92 \mathrm{Kg} \mathrm{COD} / \mathrm{m}^{3} /$ day $(\mathrm{STD} \pm 0.64)$, this effective control aided in keeping COD removal efficiencies in excess of $72 \%$ for the duration of the start up. Mean organic loading rates (table 4) were well within the design limit of $5.60 \mathrm{Kg} \mathrm{COD} / \mathrm{m}^{3} /$ day and below the expected operational level of $4 \mathrm{Kg}$ $\mathrm{COD} / \mathrm{m}^{3} /$ day for all periods, with the highest mean being seen between days $90-120$ at an OLR of $2.98 \mathrm{Kg} \mathrm{COD} / \mathrm{m}^{3} /$ day $(\mathrm{STD} \pm 0.54)$.

Optimal mesophillic conditions of $35^{\circ} \mathrm{C}-38^{\circ} \mathrm{C}$ (Bolzonella et al., 2012) were achieved within the first 9 days of operation due to the high temperature of the incoming effluent. After the $66^{\text {th }}$ day temperatures were in excess of this optimum range on all but 1 day and reaching a 
maximum of $42.1^{\circ} \mathrm{C}$. Although outside of the optimum levels conditions were within the range of mesophilic digestion and showed no noticeable decrease in reactor performance in terms of COD removal. This finding is in accordance with long term performance trends shown in Cairns \& Mead (2017) which showed that the plant remained robust when operating at higher than optimum temperatures.
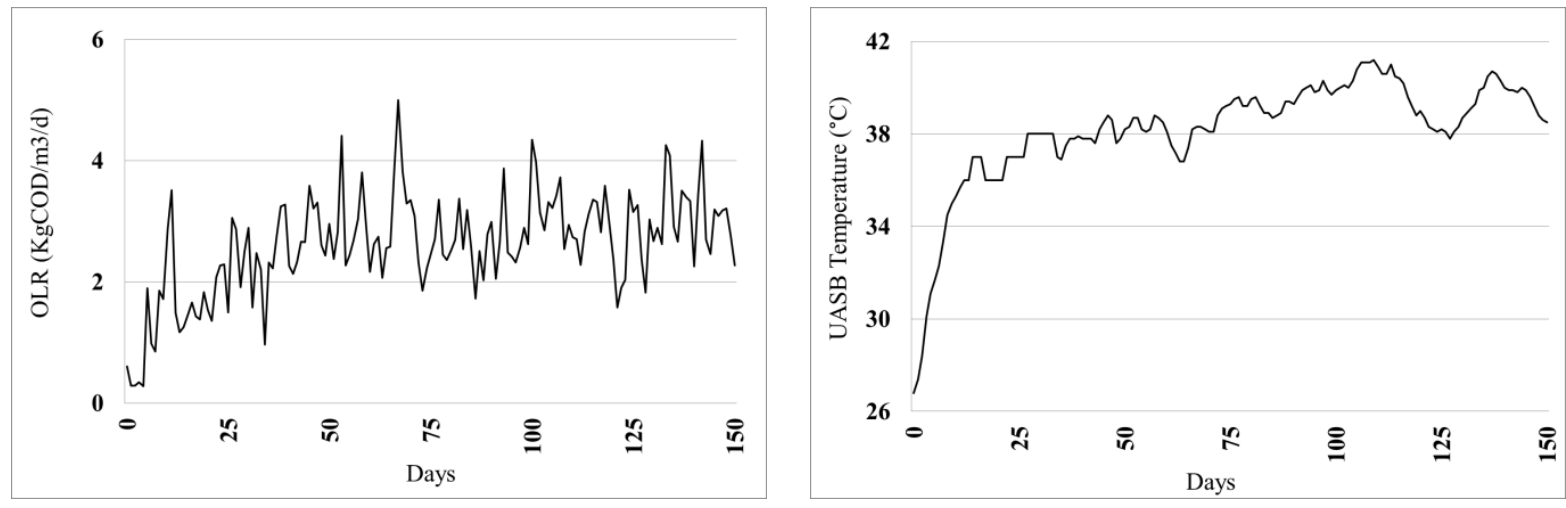

Figure 4. Organic Loading Rate $\left(\mathrm{KgCOD} / \mathrm{m}^{3} / \mathrm{d}\right)$

Figure 5. UASB effluent temperature $\left({ }^{\circ} \mathrm{C}\right)$

Volatile Fatty Acid concentration steadily increased inline with the OLR however a large spike on $67^{\text {th }}$ day which saw the OLR double to $5.00 \mathrm{KgCOD} / \mathrm{m}^{3} / \mathrm{d}$ and was followed by a large spike in VFAs two days later and continued to fluctuate around the mean of $696 \mathrm{mg} / \mathrm{L}$ (STD $\pm 172 \mathrm{mg} / \mathrm{L})$. A VFA profile was not conducted as part of this study although this could have helped provide insight in to whether the plant was performing under optimum, normal or stressed conditions (Horan et al., 2011). A understanding of the VFA ratios could be used to aid fine tune the digester by optimising key plant operating parameters such as hydraulic retention time and organic loading rate.

Table 3. Process Parameters

\begin{tabular}{|l|c|c|c|c|c|}
\hline Parameter & 0-30days & 30-60days & 60 -90days & 90 -120days & 120 -150 days \\
\hline Flow $\left(\mathrm{m}^{3} / \mathrm{d}\right) \pm \mathrm{STD}$ & $135.39 \pm 56.95$ & $193.39 \pm 48.14$ & $213.77 \pm 34.33$ & $217.19 \pm 20.35$ & $201.74 \pm 39.52$ \\
\hline HRT $($ days $) \pm \mathrm{STD}$ & $22.14 \pm 21.20$ & $10.99 \pm 3.27$ & $9.57 \pm 2.00$ & $9.20 \pm 0.90$ & $10.19 \pm 2.05$ \\
\hline $\mathrm{V}_{\text {up }}(\mathrm{m} / \mathrm{s}) \pm \mathrm{STD}$ & $0.03 \pm 0.01$ & $0.04 \pm 0.01$ & $0.04 \pm 0.01$ & $0.04 \pm 0.01$ & $0.04 \pm 0.01$ \\
\hline OLR $\left(\mathrm{KgCOD} / \mathrm{m}^{3} /\right.$ day $) \pm \mathrm{STD}$ & 1.660 .86 & $2.68 \pm 0.65$ & $2.77 \pm 0.67$ & $2.98 \pm 0.54$ & $2.91 \pm 0.68$ \\
\hline Temperature $\left({ }^{\circ} \mathrm{C}\right) \pm \mathrm{STD}$ & $34.89 \pm 3.18$ & $38.06 \pm 0.48$ & $38.63 \pm 0.82$ & $40.16 \pm 0.64$ & $39.19 \pm 0.86$ \\
\hline $\mathrm{pH} \pm \mathrm{STD}$ & $6.89 \pm 0.17$ & $7.16 \pm 0.13$ & $7.16 \pm 0.11$ & $7.61 \pm 0.21$ & $7.75 \pm 0.08$ \\
\hline $\mathrm{VFA}(\mathrm{mg} / \mathrm{l}) \pm \mathrm{STD}$ & $235.52 \pm 82.13$ & $391.61 \pm 96.75$ & $734.32 \pm 221.01$ & $656.90 \pm 148.74$ & $646.00 \pm 135.72$ \\
\hline COD Removal $(\%) \pm \mathrm{STD}$ & $95.46 \pm 2.26$ & $89.82 \pm 3.22$ & $81.89 \pm 4.84$ & $85.05 \pm 1.65$ & $82.76 \pm 3.03$ \\
\hline
\end{tabular}

Treated effluent $\mathrm{pH}$ was also seen to steadily increase (Figure. 7) from a mean of 6.89 $(\mathrm{STD} \pm 0.17)$ in the first 30 days to $7.75(\mathrm{STD} \pm 0.7)$ in the last 30 days (table 3 ). This rise occurred without any chemical addition despite wide variations in incoming $\mathrm{pH}$ (3.15 11.83). 


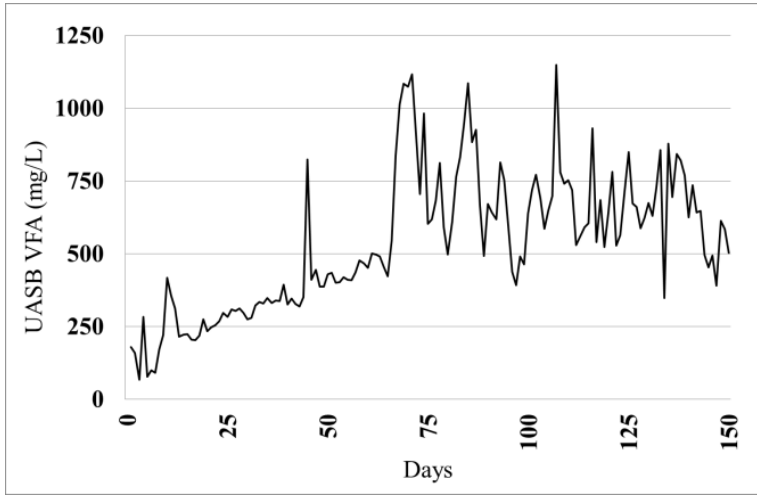

Figure 6. Volatile Fatty Acids (mg/l)

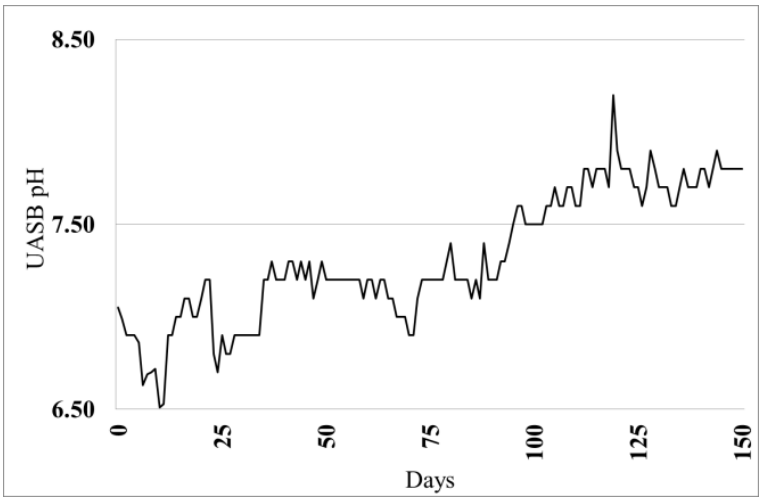

Figure 7. Reactor $\mathrm{pH}$

\subsection{Start Up: Treated Water}

Over the 150 day start up sampling period the treated effluent had a COD concentration increase from $1029 \mathrm{mg} / \mathrm{L}(\mathrm{STD} \pm 758)$ in the first 30 days to $4828 \mathrm{mg} / \mathrm{L}(\mathrm{STD} \pm 484)$ in the last 30 days. A similar increasing trend in $\mathrm{N}$ and $\mathrm{P}$ was witnessed increasing from $31.79 \mathrm{mg} / \mathrm{L}$ $(\mathrm{STD} \pm 9.45)$ and $27.62 \mathrm{mg} / \mathrm{L}(\mathrm{STD} \pm 14.55)$ in the first 30 days to $171.25 \mathrm{mg} / \mathrm{L}(\mathrm{STD} \pm 484)$ and $102.3 \mathrm{mg} / \mathrm{L}(\mathrm{STD} \pm 48.50)$ in the last 30 days respectively. This leads to a mean treated effluent CNP ratio ranging from of roughly 37:1:1 in the first 30 days to 48: 2:1 in the last 30 days. This could therefore cause issues with downstream aerobic process where a CNP ratio of 100:5:1 is desired (Ammary, 2004). Increases in the OLR has been shown to not only have a deleterious impact on overall residual COD (Figure 8) but also on COD removal efficiency (Figure 9).

Sulphate continued to be relatively low compared to COD increasing from a mean concentration of $146.61 \mathrm{mg} / \mathrm{L}(\mathrm{STD} \pm 22.22)$ during the first thirty days to $538.39 \mathrm{mg} / \mathrm{L}$ (STD \pm 78.53 ), this results $\mathrm{COD}: \mathrm{SO}_{4}$ ratio ranging from 7:1 at the beginning of the start up to 9:1 at the end of the start up. This is comparable to $\mathrm{COD}: \mathrm{SO}_{4}$ ratio of 8.5:1 during long term operations (Cairns and Mead, 2017).

Table 4. Treated Wastewater Composition

\begin{tabular}{|l|l|l|l|l|l|}
\hline Parameter & $0-30$ days & $30-60$ days & $60-90$ days & $90-120$ days & $120-150$ days \\
\hline $\mathrm{COD}(\mathrm{mg} / \mathrm{L})$ & $1029 \pm 465$ & $2790 \pm 808$ & $4476 \pm 604$ & $4010 \pm 296$ & $4828 \pm 484$ \\
\hline $\mathrm{TKN}(\mathrm{mg} / \mathrm{L})$ & $31.79 \pm 9.45$ & $99.60 \pm 41.50$ & $137.80 \pm 33.97$ & $175.50 \pm 43.62$ & $171.25 \pm 49.74$ \\
\hline $\mathrm{P}(\mathrm{mg} / \mathrm{L})$ & $27.62 \pm 14.55$ & $77.34 \pm 8.08$ & $87.22 \pm 8.63$ & $82.33 \pm 1.14$ & $102.30 \pm 48.50$ \\
\hline $\mathrm{TSS}(\mathrm{mg} / \mathrm{L})$ & $610.73 \pm 786.39$ & $1420.84 \pm 443.91$ & $1965.03 \pm 292.57$ & $1672.74 \pm 257.01$ & $2606.00 \pm 465.92$ \\
\hline $\mathrm{SO}_{4}(\mathrm{mg} / \mathrm{L})$ & $146.61 \pm 22.22$ & $349.79 \pm 130.09$ & $413.58 \pm 143.25$ & $360.55 \pm 56.59$ & $538.39 \pm 78.53$ \\
\hline
\end{tabular}

Due to technical issues with gas meters, accurate data pertaining total biogas gas production, total methane production and Biological Methane Potential (BMP) was not possible. Under higher OLRs it was noticed that the plant became less efficient with regards to the \% methane concentration of the biogas (Figure 9), which is comparable to post start up conditions (Cairns \& Mead, 2017) with mean methane concentrations of 57.24\% (STD \pm 4.29 ) and 58.08 $(\mathrm{STD} \pm 2.96)$ respectively. 


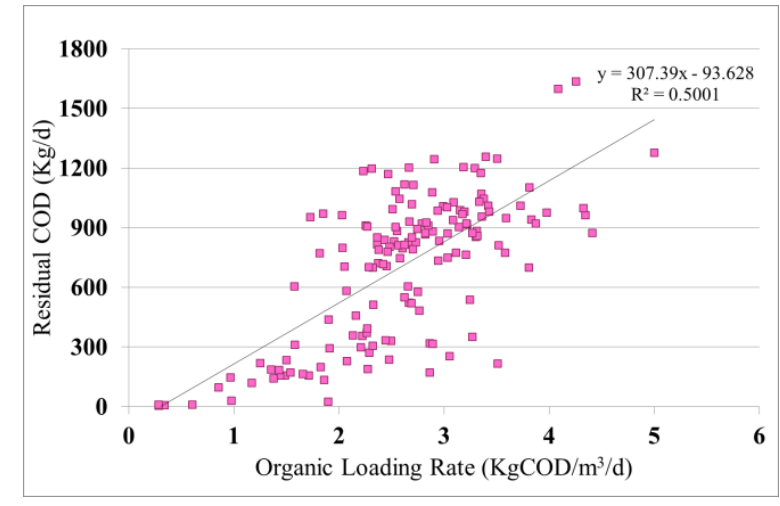

Figure 8. The impact of OLR on residual COD

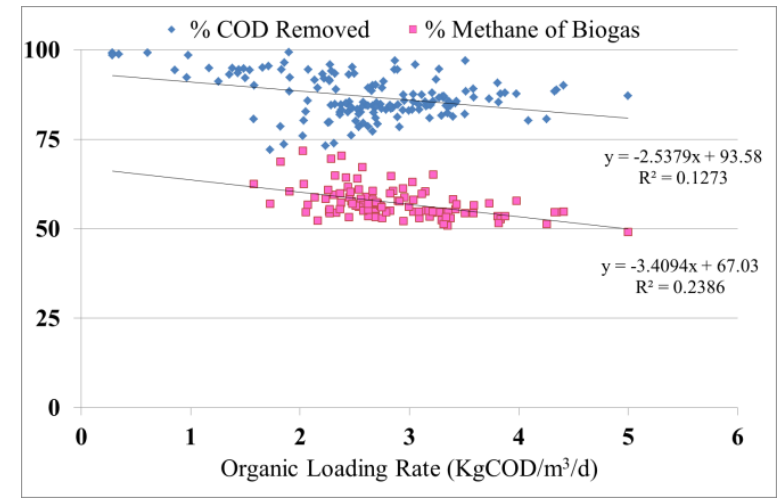

Figure 9. Impact of OLR on \% COD removal and \% Methane in biogas

\section{Conclusion}

In this paper it was demonstrated that an Upflow Anaerobic Sludge Blanket under mesophilic conditions treating a high strength effluent $(15,619$ - 44,684mg/L COD) from a malted ingredients factory could be started effectively within a period 75 days.

Despite previously reported difficulties with plant start ups, operational performance in terms COD removal efficiency $(>81.89 \% \pm 4.84)$ and the percentage methane content of biogas $(57.24 \% \pm 4.29)$ was achieved at a level comparable to a fully established plant. Further work is required to determine if total biogas volumes are also comparable.

Operational performance was considered robust with the main factor limiting COD removal efficiency and biogas methane concentration being the organic loading rate. Typically key operational parameters such as HRT times, temperatures and $\mathrm{pH}$ were outside ideal plant operating parameters but did no exert a strong influence on plant performance. It would be beneficial to conduct a profile of the VFA to be able to get a better insight in to the plant operating conditions as well as understanding the micronutrient composition of the incoming wastewater.

\section{Acknowledgement}

The authors would like to thank Fontus Environmental and Muntons PLC for supporting this research project with particular thanks to Lawrence Howes, Francis Rowlands, Philip Jacobs and Dr Nigel Davies. Acknowledgement also goes to ADBA and their Chief Executive Charlotte Morton for her continued hard work in promoting developments in the UK AD industry and Jessica Allan for her work on the AD Operator Best Practice Scheme.

\section{References}

ADBA. (2016). Anaerobic Digestion Market Report: December. [Online] Available: http://adbioresources.org/docs/marketreport-dec-2016-40ppa4_v1.pdf (May 15, 2017)

Alphenaar, P. A. (1994), Anaerobic granular sludge: characterisation and factors affecting it functioning PhD thesis Agricultural University of Wageningen; Netherlands, 61-72.

Alvarez, J. A., Ruiz, I., Gómez, M., Presas, J., \& Soto, M. (2006). Start-up alternatives and 
performance of an UASB pilot plant treating diluted municipal wastewater at low temperature. Bioresource Technology, 97(14), 1640-1649.

https://doi.org/10.1016/j.biortech.2005.07.033

Ammary, B. Y. (2004). Nutrients requirements in biological industrial wastewater treatment. African Journal of Biotechnology, 3(4), 236-238. https://doi.org/10.5897/AJB2004.000-2042

American Public Health Association, American Water Works Association, Water Pollution Control Federation, \& Water Environment Federation. (2012). Standard methods for the examination of water and wastewater (Vol. 22). American Public Health Association

Bekkering, J., Benders, R. M. J., Moll, H. C., \& Pierie, F. (2016). Spatial and environmental assessment of energy potentials for Anaerobic Digestion production systems applied to the Netherlands. Applied Energy, 176, 233-244. https://doi.org/10.1016/j.apenergy.2016.05.055

Bolzonella, D., Cavinato, C., Fatone, F., Pavan, P., \& Cecchi, F. (2012). High rate mesophilic, thermophilic, and temperature phased anaerobic digestion of waste activated sludge: a pilot scale study. Waste Management, 32(6), 1196-1201.

https://doi.org/10.1016/j.wasman.2012.01.006

Borzacconi, L., López, I., \& Passeggi, M. (2006). Start-up and steady-state results of a full-scale UASB reactor treating malting wastewater. Water science and technology, 54(2), 261-267.

Cairns, R., \& Mead, P. (2017). Performance of a UASB Effluent Treatment Plant Treating Malt Ingredient Manufacturing Wastewater. Environmental Management and Sustainable Development, 6(2), 198-210. https://doi.org/10.5296/emsd.v6i2.11314

Carrere, H., Antonopoulou, G., Affes, R., Passos, F., Battimelli, A., Lyberatos, G., \& Ferrer, I. (2016). Review of feedstock pretreatment strategies for improved anaerobic digestion: from lab-scale research to full-scale application. Bioresource technology, 199, 386-397. https://doi.org/10.1016/j.biortech.2015.09.007

Chávez, P. C., Castilllo, L.R., Dendooven, L., \& Escamilla-Silva, E. M. (2005). Poultry slaughter wastewater treatment with an up-flow anaerobic sludge blanket (UASB) reactor. Bioresource technology, 96(15), 1730-1736. https://doi.org/10.1016/j.biortech.2004.08.017

Chen, Y., Cheng, J. J., \& Creamer, K. S. (2008). Inhibition of anaerobic digestion process: a review. Bioresource technology, 99(10), 4044-4064.

https://doi.org/10.1016/j.biortech.2007.01.057

Conceição, V., Freire, F. B., \& de Carvalho, K. Q. (2012). Treatment of textile effluent containing indigo blue dye by a UASB reactor coupled with pottery clay adsorption. Acta Scientiarum. Technology, 35(1), 53-58. https://doi.org/10.4025/actascitechnol

De Baere, L., \& Mattheeuws, B. (2012). Anaerobic digestion of the organic fraction of municipal solid waste in Europe: Status, experience and prospects. In Thomé-Kozmiensky Karl J., Thiel S (Eds). Waste Management, Vol. 3, Recycling and Recovery, 517-526 


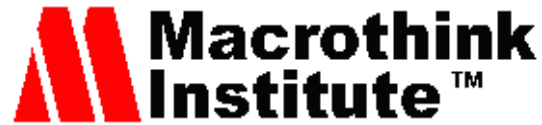

Environmental Management and Sustainable Development

ISSN 2164-7682

2018, Vol. 7, No. 2

Ersahin, M. E., Ozgun, H., Dereli, R. K., \& Ozturk, I. (2011). Anaerobic treatment of industrial effluents: an overview of applications. Waste Water, Treatment and Reutilization, $1-27$.

Facchin, V., Cavinato, C., Fatone, F., Pavan, P., Cecchi, F., \& Bolzonella, D. (2013). Effect of trace element supplementation on the mesophilic anaerobic digestion of foodwaste in batch trials: the influence of inoculum origin. Biochemical engineering journal, 70, 71-77. https://doi.org/10.1016/j.bej.2012.10.004

Hernández, M., \& Rodríguez, M. (2013). Hydrogen production by anaerobic digestion of pig manure: Effect of operating conditions. Renewable energy, 53, 187-192.

https://doi.org/10.1016/j.renene.2012.11.024

Horan, N. J., Smyth, M., \& May, A. (2011). Optimisation of digester performance and gas yield through analysis of VFA speciation. In 16th European Bio-solids and Organic Resources Conference.

Huang, J. S., Wu, C. S., \& Chen, C. M. (2005). Microbial activity in a combined UASB-activated sludge reactor system. Chemosphere, 61(7), 1032-1041.

https://doi.org/10.1016/j.chemosphere.2005.03.027

Huang, L., Zhang, B., Gao, B., \& Feng, L. (2009, October). Application of anaerobic granular sludge to treatment of fishmeal industry wastewaters under highly saline conditions. In Energy and Environment Technology, 2009. ICEET'09. International Conference on (Vol. 2, pp. 433-436). IEEE. https://doi.org/10.1109/iceet.2009.343

Kamali, M., Gameiro, T., Costa, M. E. V., \& Capela, I. (2016). Anaerobic digestion of pulp and paper mill wastes-An overview of the developments and improvement opportunities. Chemical Engineering Journal, 298, 162-182. https://doi.org/10.1016/j.cej.2016.03.119

Kalogo, Y. and Verstraete, W. (2001). Potentials of anaerobic treatment of domestic sewage under temperate climate conditions. In Decentralised sanitation and reuse: concepts, systems and implementation (pp. 181-204). IWA Publishing.

Koller, T. (2016). ADBA MEMBER'S PRESS RELEASE; Muntons project on the shortlist for another energy industry award. [Online] Available: MEMBER'S PRESS RELEASE: Muntons project on the shortlist for another energy industry award (May 18, 2017)

Latif, M. A., Ghufran, R., Wahid, Z. A., \& Ahmad, A. (2011). Integrated application of upflow anaerobic sludge blanket reactor for the treatment of wastewaters. Water research, 45(16), 4683-4699. https://doi.org/10.1016/j.watres.2011.05.049

Leite, W. R. M., Gottardo, M., Pavan, P., Belli Filho, P., \& Bolzonella, D. (2016). Performance and energy aspects of single and two phase thermophilic anaerobic digestion of waste activated sludge. Renewable Energy, 86, 1324-1331.

https://doi.org/10.1016/j.renene.2015.09.069

Lettinga, G., De Man, A., Van der Last, A. R. M., Wiegant, W., Van Knippenberg, K., Frijns, J., \& Van Buuren, J. C. L. (1993). Anaerobic treatment of domestic sewage and 
wastewater. Water Science and Technology, 27(9), 67-73.

Micolucci, F., Gottardo, M., Cavinato, C., Pavan, P., \& Bolzonella, D. (2016). Mesophilic and thermophilic anaerobic digestion of the liquid fraction of pressed biowaste for high energy yields recovery. Waste management, 48, 227-235.

https://doi.org/10.1016/j.wasman.2015.09.031

Moraes, B. S., Zaiat, M., \& Bonomi, A. (2015). Anaerobic digestion of vinasse from sugarcane ethanol production in Brazil: Challenges and perspectives. Renewable and Sustainable energy reviews, 44, 888-903. https://doi.org/10.1016/j.rser.2015.01.023

Musee, N., Trerise, M. A., \& Lorenzen, L. (2016). Post-treatment of distillery wastewater after UASB using aerobic techniques. South African Journal of Enology and Viticulture, 28(1), 50-55. https://doi.org/10.21548/28-1-1459

Rajakumar, R., Meenambal, T., Banu, J. R., \& Yeom, I. T. (2011). Treatment of poultry slaughterhouse wastewater in upflow anaerobic filter under low upflow velocity. International Journal of Environmental Science \& Technology, 8(1), 149-158.

https://doi.org/10.1007/BF03326204

Rajeshwari, K. V., Balakrishnan, M., Kansal, A., Lata, K., \& Kishore, V. V. N. (2000). State-of-the-art of anaerobic digestion technology for industrial wastewater treatment. Renewable and Sustainable Energy Reviews, 4, 135-156.

https://doi.org/10.1016/S1364-0321(99)00014-3

Rizvi, H., Ahmad, N., Abbas, F., Bukhari, I. H., Yasar, A., Ali, S., Tahira, Y., \& Riaz, M. (2015). Start-up of UASB reactors treating municipal wastewater and effect of temperature/sludge age and hydraulic retention time (HRT) on its performance. Arabian Journal of Chemistry, 8(6), 780-786. https://doi.org/10.1016/j.arabjc.2013.12.016

Satyawali, Y., \& Balakrishnan, M. (2008). Wastewater treatment in molasses-based alcohol distilleries for COD and color removal: a review. Journal of Environmental Management, 86(3), 481-497. https://doi.org/10.1016/j.jenvman.2006.12.024

Schmidt, J. E., \& Ahring, B. K. (1996). Granular sludge formation in upflow anaerobic sludge blanket (UASB) reactors. Biotechnology and bioengineering, 49(3), 229-246. https://doi.org/10.1002/(SICI)1097-0290(19960205)49:3<229::AID-BIT1>3.0.CO;2-M

Siang, Lee Chee. "Biodegradation of oil and grease in upflow anaerobic sludge blanket reactor for palm oil mill effluent treatment." Masters degree thesis. Universiti Teknologi Malaysia, Malaysia (2006).

Singh, K. S., Viraraghavan, T., Karthikeyan, S., \& Caldwell, D. E. (1997). Low temperature start-up of UASB reactors for municipal wastewater treatment. In Proc. 8th Intl. Conf. on Anaerobic Digestion (pp. 192-195).

Singh, L., Wahid, Z. A., Siddiqui, M. F., Ahmad, A., Rahim, M. H. A., \& Sakinah, M. (2013). Application of immobilized upflow anaerobic sludge blanket reactor using Clostridium LS2 for enhanced biohydrogen production and treatment efficiency of palm oil mill effluent. 


\section{Macrothink \\ Environmental Management and Sustainable Development \\ ISSN 2164-7682 2018, Vol. 7, No. 2}

international journal of hydrogen energy, 38(5), 2221-2229.

https://doi.org/10.1016/j.ijhydene.2012.12.004

Surendra, K. C., Takara, D., Jasinski, J., \& Kumar, Khanal, S. (2013). Household anaerobic digester for bioenergy production in developing countries: opportunities and challenges. Environmental technology, 34(13-14), 1671-1689.

https://doi.org/10.1080/09593330.2013.824012

Tawfik, A., Sobhey, M., \& Badawy, M. (2008). Treatment of a combined dairy and domestic wastewater in an up-flow anaerobic sludge blanket (UASB) reactor followed by activated sludge (AS system). Desalination, 227(1-3), 167-177.

https://doi.org/10.1016/j.desal.2007.06.023

Yu, H. Q., Fang, H. H., \& Gu, G. W. (2002). Comparative performance of mesophilic and thermophilic acidogenic upflow reactors. Process Biochemistry, 38(3), 447-454.

https://doi.org/10.1016/S0032-9592(02)00161-9

Wang, W., Wu, B., Pan, S., Yang, K., Hu, Z., \& Yuan, S. (2017). Performance robustness of the UASB reactors treating saline phenolic wastewater and analysis of microbial community structure. Journal of Hazardous Materials, 331, 21-27.

https://doi.org/10.1016/j.jhazmat.2017.02.025

Wolmarans, B., \& De Villiers, G. H. (2002). Start-up of a UASB effluent treatment plant on distillery wastewater. Water $S A, 28(1), 63-68$.

Zhang, S. J., Liu, N. R., \& Zhang, C. X. (2013). Study on the performance of modified UASB process treating sewage. Advanced Materials Research, 610, 2174-2178.

\section{Glossary}

AD: Anaerobic Digestion

ADBA: The Anaerobic Digestion and Bioresources Association

$\mathrm{CH}_{4}$ : Methane

COD: Chemical Oxygen Demand

HRT: Hydraulic Retention Time

MI: Malt Ingredients

$\mathrm{NH}_{3}$ : Ammonia

OLR: Organic Loading Rate

TKN: Total kjeldahl (Organic) Nitrogen

TSS: Total Suspended Solids

UASB: Upflow Anaerobic Sludge Blanket

VFA: Volatile Fatty Acids 


\section{Macrothink

$\mathrm{V}_{\text {up }}$ : Upflow Velocity

\section{Copyright Disclaimer}

Copyright for this article is retained by the author(s), with first publication rights granted to the journal.

This is an open-access article distributed under the terms and conditions of the Creative Commons Attribution license (http://creativecommons.org/licenses/by/3.0/). 